\title{
Stabilization of Submicron Calcium Oxalate Suspension by Chondroitin Sulfate C May Be an Efficient Protection from Stone Formation
}

\author{
Jun-Jun Li, ${ }^{1,2}$ Jun-Fa Xue, ${ }^{2}$ and Jian-Ming Ouyang ${ }^{2}$ \\ ${ }^{1}$ College of Pharmacy, Guangdong Pharmaceutical University, Guangzhou 510006, China \\ ${ }^{2}$ Institute of Biomineralization and Lithiasis Research, Jinan University, Guangzhou 510632, China \\ Correspondence should be addressed to Jian-Ming Ouyang; toyjm@jnu.edu.cn
}

Received 5 July 2013; Revised 26 October 2013; Accepted 10 November 2013

Academic Editor: Imre Sovago

Copyright (C) 2013 Jun-Jun Li et al. This is an open access article distributed under the Creative Commons Attribution License, which permits unrestricted use, distribution, and reproduction in any medium, provided the original work is properly cited.

\begin{abstract}
The influences of chondroitin sulfate $\mathrm{C}\left(\mathrm{C}_{6} \mathrm{~S}\right)$ on size, aggregation, sedimentation, and Zeta potential of sub-micron calcium oxalate monohydrate (COM) and calcium oxalate dihydrate (COD) crystallites with mean sizes of about $330 \mathrm{~nm}$ were investigated using an $\mathrm{X}$-ray diffractometer, nanoparticle size Zeta potential analyzer, ultraviolet spectrophotometer, and scanning electron microscope, after which the results were compared with those of micron-grade crystals. $\mathrm{C}_{6} \mathrm{~S}$ inhibited the conversion of COD to COM and the aggregation of COM and COD crystallitesis; it also decreased their sedimentation rate, thus increasing their stability in aqueous solution. The smaller the size of the COD crystallites, the easier they can be converted to COM. The stability of sub-micron COD was worse than that of micron-grade crystals. $\mathrm{C}_{6} \mathrm{~S}$ can inhibit the formation of calcium oxalate stones.
\end{abstract}

\section{Introduction}

The formation of urinary stones is closely related to supersaturation, nucleation, growth, and aggregation of stone salt. Compared with the urine of stone patients, normal urine has more types of inhibitors with higher concentration and stronger activity. These inhibitors include some small-molecule inorganic salts such as citrate and pyrophosphate and urinary macromolecules such as glycosaminoglycan (GAG), nephrocalcin, Tamm-Horsfall protein, and prothrombin fragment $1[1-5]$. As the main component of urinary stones, calcium oxalate $(\mathrm{CaOxa})$ mainly exists in the form of calcium oxalate monohydrate (COM) and calcium oxalate dehydrate (COD). In the urine of patients afflicted with urinary stones, the existing probability of COM crystallites is much higher than that in healthy controls [6].

A study showed that $\mathrm{CaOxa}$ crystals in urine only take $3 \mathrm{~min}$ to $4 \mathrm{~min}$ to flow through the nephron [7] and about $12 \mathrm{~min}$ to pass through the pelvis. Within such a short time, the crystal could not grow into a pathological size (larger than tens of microns). Rapid aggregation of the crystals is an important factor in CaOxa stone formation $[8,9]$.
GAG is an important urinary macromolecule that inhibits urinary stone formation [2]. Urinary GAGs originate from two sources. The first source of urinary GAGs is the serum, which is filtered through the kidney into the urine. The electrophoretic types of GAGs in urine are similar to those present in the serum; moreover, the excretion of urinary GAGs increases along with the increment of GAG concentration in the serum [10-12]. The GAGs in the serum originate from degradation products of proteoglycans in connective tissues, such as the cartilage, intervertebral disk, cornea, skin, blood vessels, hemocyte, and thrombocyte, as well as other organs, such as the brain, kidneys, and the liver. The GAGs in these tissues and organs often combine with proteins and exist as proteoglycans. The second source of urinary GAGs is the urinary tract. The urinary tract, especially the bladder surface, can secrete GAGs [13]. Consequently, the concentration of urinary GAG gradually increases down the urinary tract. The GAGs formed in the urinary tract can form a GAG layer on the surface, inhibiting the adhesion of urinary crystallites to cells and the formation of renal calculi.

GAGs excreted in the urine include eight components: chondroitin sulfate $A\left(\mathrm{C}_{4} \mathrm{~S}\right)$, chondroitin sulfate $\mathrm{C}\left(\mathrm{C}_{6} \mathrm{~S}\right)$, 
chondroitin $(\mathrm{CH})$, hyaluronic acid (HA), heparan sulfate (HS), dermatan sulfate (DS), heparin (HP), and keratin sulfate (KS) [14-16].

The concentration of GAGs in the $24 \mathrm{~h}$ urine of patients afflicted with urinary stones is significantly lower than that in controls. The former exhibits a concentration of $2.97 \pm$ $0.43 \mathrm{mg} / \mathrm{L}$ (male) and $2.32 \pm 0.24 \mathrm{mg} / \mathrm{L}$ (female), whereas the latter shows a concentration of $8.22 \pm 0.60 \mathrm{mg} / \mathrm{L}$ (male) and $7.97 \pm 0.43 \mathrm{mg} / \mathrm{L}$ (female) [17]. The concentrations of GAGs $(5.62 \mu \mathrm{g} / \mathrm{mg})$ and chondroitin sulfate $(2.81 \mu \mathrm{g} / \mathrm{mg})$ in the urine of the control subjects were higher than those (4.75 and $1.67 \mu \mathrm{g} / \mathrm{mg}$, resp.) of the stone-forming patients [16]. In the literature [18], the concentration of GAGs in the control subjects' urine $(6.20 \pm 0.68 \mathrm{mg} / \mathrm{dL})$ was higher than that in the stone-forming patients (uric acid stones: $3.77 \pm 0.68$; CaOxa stones: $5.16 \pm 0.55$; CaP stones: $3.88 \pm 0.79 \mathrm{mg} / \mathrm{dL}$ ). The incidence of pediatric urolithiasis is less in adults due to the higher GAG concentration in children's urine (children: $10.2 \pm 0.58 \mathrm{mg} / \mathrm{L}$, adult: $5.06 \pm 0.47 \mathrm{mg} / \mathrm{L}$ ) [19].

GAGs can inhibit the nucleation, growth, and aggregation of $\mathrm{CaOxa}$ stones [20]. Out of the eight components of GAGs, chondroitin sulfate $\left(\mathrm{CS}\right.$, including $\mathrm{C}_{6} \mathrm{~S}$ and $\left.\mathrm{C}_{4} \mathrm{~S}\right)$ is responsible for the main inhibitory effect of GAGs [14]. About $55 \%$ of GAGs in the urine of the control subjects were CS, whereas only $35 \%$ of those in the urine of stoneforming patients were CS [16]. $\mathrm{C}_{6} \mathrm{~S}$ is a linear polysaccharide polyanion. Each repeating disaccharide unit has a negatively charged sulfate group and carboxylic group [21].

Only a few reports on submicron CaOxa crystals exist $[22,23]$. Therefore, the effect of $\mathrm{C}_{6} \mathrm{~S}$ on aggregation and sedimentation of COM and COD crystallites with mean size of about $330 \mathrm{~nm}$ was investigated in this article to study further the formation mechanism of urinary stones.

\section{Experimental Section}

2.1. Reagents and Apparatus. $\mathrm{C}_{6} \mathrm{~S}$ was produced by Sigma Co. All reagents were analytical grade, and the water used was double-distilled.

The samples were characterized by a D/max 2400 type $\mathrm{X}$-ray powder diffractometer (Rigaku, JP), Zetasizer $300 \mathrm{HS}$ nanoparticle size Zeta potential analyzer (Malvern, UK), TU1900 double-beam UV spectrophotometer (Beijing Purkinje General Instrument Co.), and Philips XL-30 scanning electron microscope.

\subsection{Preparation and Characterization of Submicron COM and} COD. Preparation of COM crystallites was done as follows: up to $50 \mathrm{~mL}$ of $0.30 \mathrm{~mol} / \mathrm{L} \mathrm{KAc}$ and $50 \mathrm{~mL}$ of $0.30 \mathrm{~mol} / \mathrm{L}$ $\mathrm{CaCl}_{2}$ were added into a $250 \mathrm{~mL}$ beaker at $30^{\circ} \mathrm{C}$ under intense stirring. Then, $50 \mathrm{~mL}$ of $0.30 \mathrm{~mol} / \mathrm{L} \mathrm{K}_{2} \mathrm{C}_{2} \mathrm{O}_{4}$ was rapidly added to the mixed solution. After reacting for $6 \mathrm{~min}$, the suspension was centrifuged for $2 \mathrm{~min}$ at $4000 \mathrm{rpm}$. Finally, COM crystallites were collected and thoroughly washed with double-distilled water and ethanol alternately, and then vacuum dried at room temperature.

Preparation of COD crystallites was done as follows: after $50 \mathrm{~mL}$ of $0.30 \mathrm{~mol} / \mathrm{L}$ sodium ammonia triacetate (Na-NTA) and $50 \mathrm{~mL}$ of $0.30 \mathrm{~mol} / \mathrm{L} \mathrm{CaCl}$ solution were mixed and intensely stirred for $30 \mathrm{~min}$ at $30^{\circ} \mathrm{C}, 50 \mathrm{~mL}$ of $0.30 \mathrm{~mol} / \mathrm{L}$ $\mathrm{K}_{2} \mathrm{C}_{2} \mathrm{O}_{4}$ was added. After reacting for $5 \mathrm{~min}$, the suspension was centrifuged at $4000 \mathrm{rpm}$ for $2 \mathrm{~min}$. Finally, COD crystallites were collected and thoroughly washed with doubledistilled water and ethanol alternately and then vacuum dried at room temperature.

The purity, size, and morphology of the COM and COD crystallites were characterized by an X-ray diffractometer, nanoparticle size analyzer, and scanning electron microscope.

\subsection{Effect of $\mathrm{C}_{6} \mathrm{~S}$ on Aggregation, Zeta Potential, and Phase} Change of COM and COD Crystallites. COM or COD crystallites were added to solutions of $c\left(\mathrm{C}_{6} \mathrm{~S}\right)=0,0.05,0.1,0.2$, $0.3,0.5,2,5$, and $8 \mathrm{mg} / \mathrm{L}$ and ultrasonically dispersed for $5 \mathrm{~min}$. Up to $1.6 \mathrm{mmol} / \mathrm{L}$ of COM or COD suspension was formed. After the suspensions were stored at $37^{\circ} \mathrm{C}$ for 0 and $4 \mathrm{~h}(t=0,4 \mathrm{~h})$, the optical densities of the suspensions were measured by a UV-vis spectrometer at $620 \mathrm{~nm}$ [24]. At $t=0$, 24,48 , and $72 \mathrm{~h}$, the particle sizes and Zeta potential of the crystallites were detected by a nanoparticle size Zeta potential analyzer, and the crystal components were measured by XRD. The mass percentage of COM and COD in the crystallites was calculated according to the literature [25].

2.4. Effect of $\mathrm{C}_{6}$ S on Deposition of COM and COD Crystallites. After $2.4 \mathrm{mg} C O M$ and $2.6 \mathrm{mg}$ COD were added to $12 \mathrm{~mL}$ solutions of $c\left(\mathrm{C}_{6} \mathrm{~S}\right)=0,0.1,0.5$, and $5 \mathrm{mg} / \mathrm{L}$, respectively, suspensions of COM and COD crystallites were formed. After ultrasonic dispersion for $5 \mathrm{~min}$, the photos of the suspensions were taken at $t=0,1,2,4$, and $24 \mathrm{~h}$. The effect of $\mathrm{C}_{6} \mathrm{~S}$ concentration on the deposition of COM and COD crystallites was compared [26].

\section{Results and Discussion}

3.1. Characterization of Submicron COM and COD Crystallites. The purity, particle size, and morphology of the products were identified by an X-ray powder diffractometer, nanoparticle size analyzer, and scanning electron microscope. The results shown in Figures 1 and 2 indicate that the samples were the target products of COM and COD crystallites, with mean particle sizes of about $330 \mathrm{~nm}$.

3.2. $C_{6} S$ Inhibits COD Crystallites from Transforming into COM. COM and COD crystallites are often aggregated in aqueous solution, whereas COD crystallites easily transform into COM crystallites because the latter is more stable in thermodynamics. The conformation percentage of submicron COD into COM in the presence of different $\mathrm{C}_{6} \mathrm{~S}$ concentrations and different acting times $(t)$ was detected by XRD. The detailed detection results of XRD patterns are shown in Figure 3 and the percentage of COM in the product calculated by the results of XRD is shown in Figure 4. The following premises were deduced from Figure 4.

(1) At $c\left(\mathrm{C}_{6} \mathrm{~S}\right)=0$, no $\mathrm{C}_{6} \mathrm{~S}$ was found in the aqueous solution. The conversion percentage of $\mathrm{COD}$ was 

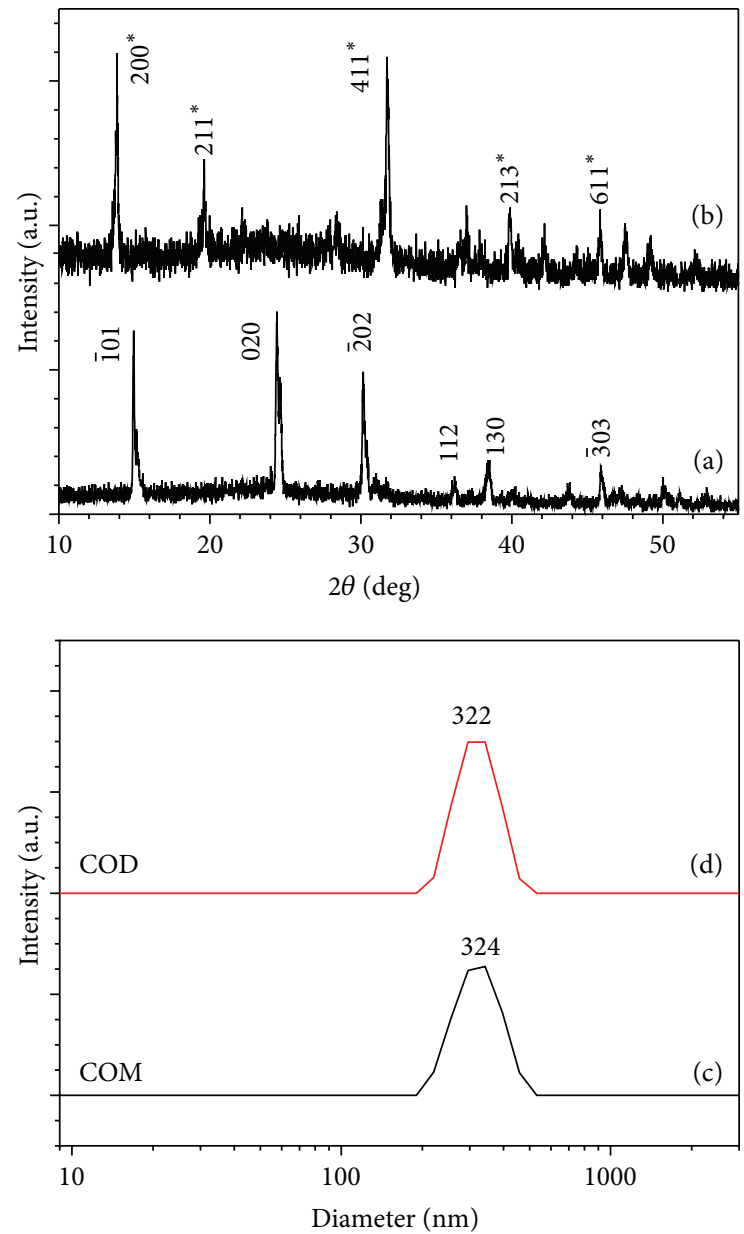

FIGURE 1: XRD patterns ( $a, b)$ and size distribution of submicron $\mathrm{CaOxa}(\mathrm{c}, \mathrm{d}) .(\mathrm{a}, \mathrm{c}) \mathrm{COM}$; (b, d) COD.

$21.3 \%, 37.7 \%$, and $100 \%$, respectively, at $t=24,48$, and $72 \mathrm{~h}$.

(2) At the same acting time, the conversion percentage of COD decreased with the increase in $c\left(\mathrm{C}_{6} \mathrm{~S}\right)$. When $c\left(\mathrm{C}_{6} \mathrm{~S}\right) \geq 5.0 \mathrm{mg} / \mathrm{L}$, no COD was converted to COM even at $t=72 \mathrm{~h}$. This finding indicated that $\mathrm{C}_{6} \mathrm{~S}$ could stabilize COD in aqueous solution.

(3) COD slowly transformed to COM with the increase in $t$. The minimum $\mathrm{C}_{6} \mathrm{~S}$ concentrations required to inhibit the conversion of submicron COD to COM in aqueous solution were $c\left(\mathrm{C}_{6} \mathrm{~S}\right)=0.1,4$, and $5 \mathrm{mg} / \mathrm{L}$ at $t=24,48$, and $72 \mathrm{~h}$, respectively.

(4) The stability of submicron COD in aqueous solution was less than that of micron-grade COD. A previous study [27] reported that a COD crystal with a size of $2 \mu \mathrm{m}$ to $3 \mu \mathrm{m}$ did not transform to COM crystal in water for $7 \mathrm{~d}$ until a small amount of COM seed was added. By contrast, submicron COD with a mean diameter of $330 \mathrm{~nm}$ could reach a higher conversion percentage within a short time in water solution. Thus, the smaller the size of the COD crystalis, the easier it can be converted to COM. COM crystallite

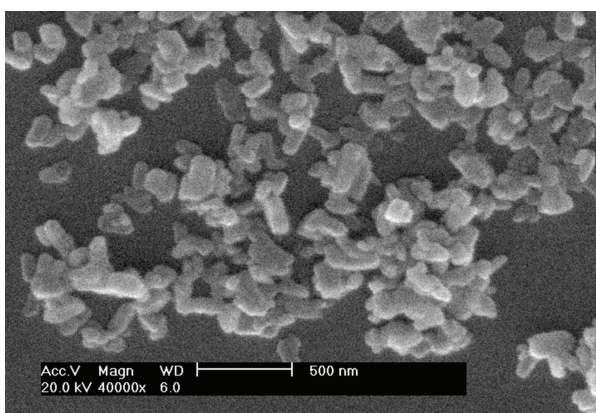

(a)

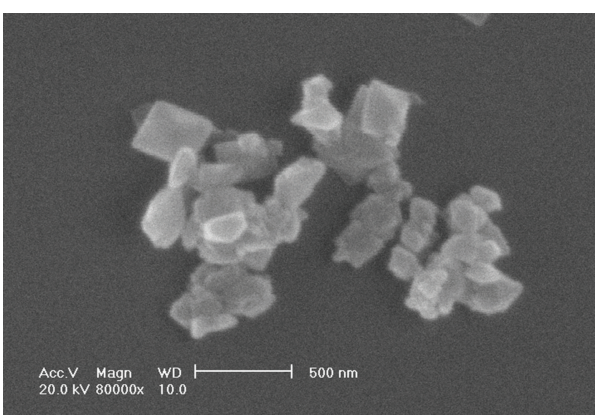

(b)

Figure 2: SEM images of submicron CaOxa. (a) COM; (b) COD.

is more harmful to the renal epithelial cell than $\mathrm{COD}$, and its adhesive capacity on the cell is stronger than that of COD [28], so the inhibition of $\mathrm{C}_{6} \mathrm{~S}$ of the transformation of COD to COM is helpful for preventing the formation of $\mathrm{CaOxa}$ stones.

3.3. $C_{6} S$ Induces the Zeta Potential on the Surface of COM and COD Crystallites to Become Negative. The Zeta potential can reflect the charge on a particle surface. The surface Zeta potential of COM and COD crystallites in the presence of different $c\left(\mathrm{C}_{6} \mathrm{~S}\right)$ concentrations is shown in Figure 5. The following were the findings obtained.

(1) The presence of $\mathrm{C}_{6} \mathrm{~S}$ induced the surface Zeta potential of both COM and COD crystallites to become negative, which was attributed to the absorbance with negatively charged $\mathrm{C}_{6} \mathrm{~S}$ on the surface of the crystallites. With the increase of $c\left(\mathrm{C}_{6} \mathrm{~S}\right)$, more $\mathrm{C}_{6} \mathrm{~S}$ was absorbed on the surface of the crystallites, so their Zeta potential became more negative. After the Zeta potential became highly negative, the electrostatic repulsion force between the crystallites increased. Therefore, the aggregation and deposition of the crystallites were inhibited, which was beneficial in restraining the formation of $\mathrm{CaOxa}$ stones.

(2) When $c\left(\mathrm{C}_{6} \mathrm{~S}\right) \leq 0.5 \mathrm{mg} / \mathrm{L}$, the Zeta potential of the crystallites quickly decreased with the increase in $c\left(\mathrm{C}_{6} \mathrm{~S}\right)$. When $c\left(\mathrm{C}_{6} \mathrm{~S}\right) \geq 0.5 \mathrm{mg} / \mathrm{L}$, their Zeta potential value slowly became negative, indicating that the adsorption of $\mathrm{C}_{6} \mathrm{~S}$ on the crystallite surface reached saturation at $c\left(\mathrm{C}_{6} \mathrm{~S}\right)=0.5 \mathrm{mg} / \mathrm{L}$. 


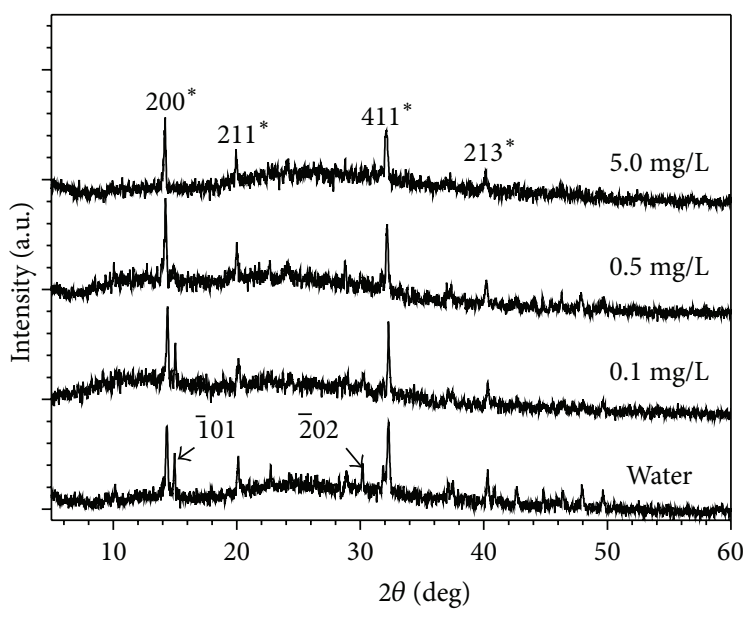

(a)

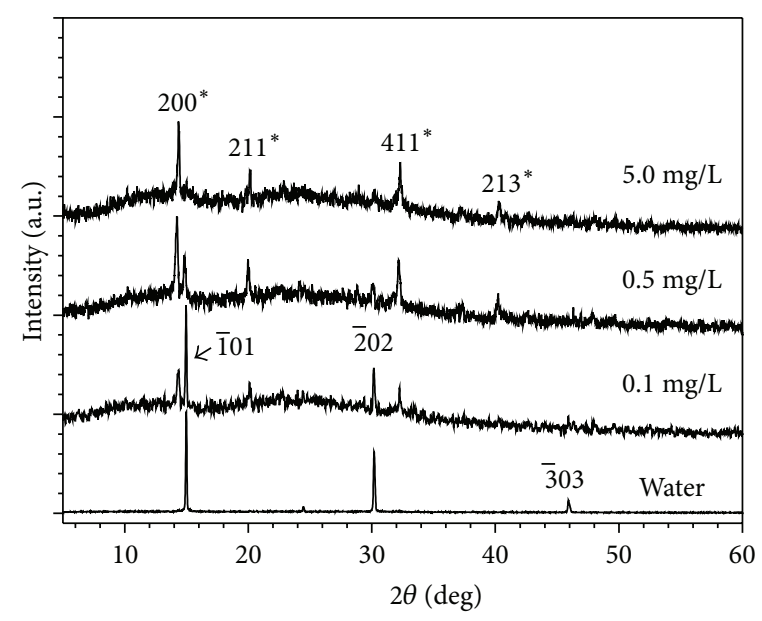

(b)

FIGURE 3: XRD patterns showing the effects of $\mathrm{C}_{6} \mathrm{~S}$ concentration on conformation percentage of submicron COD into COM in the presence of different $\mathrm{C}_{6} \mathrm{~S}$ concentrations and different acting times $(t)$. (a) $t=48 \mathrm{~h}$; (b) $t=72 \mathrm{~h}$.

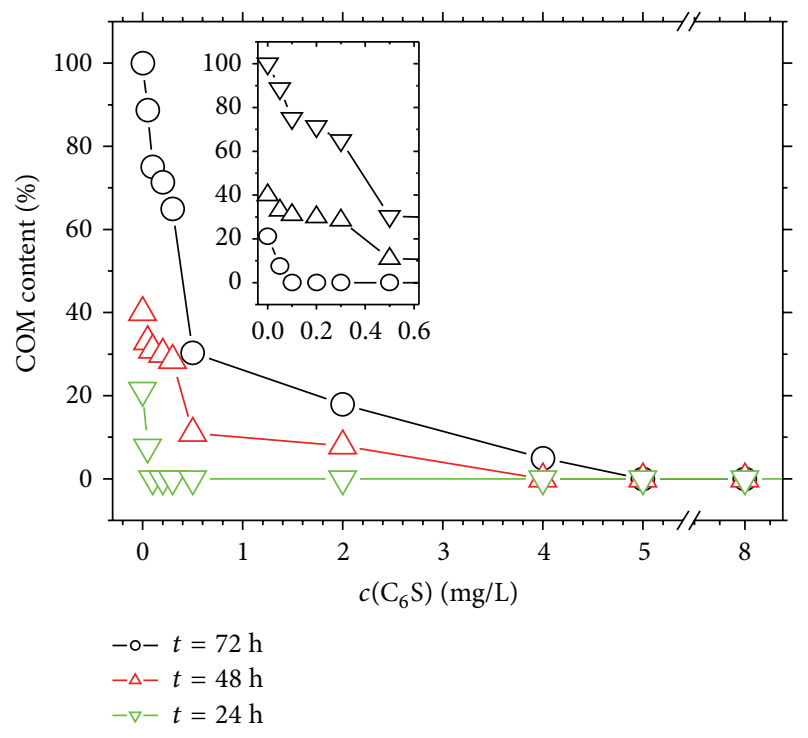

FIgURE 4: Effect of $\mathrm{C}_{6} \mathrm{~S}$ concentration $\left(c\left(\mathrm{C}_{6} \mathrm{~S}\right)\right)$ and acting time $(t)$ on transformation of submicron COD to COM.

(3) Comparing the adsorption capability of $\mathrm{COM}$ and COD by $\mathrm{C}_{6} \mathrm{~S}$ molecules, the Zeta potential of COD was slightly more negative than that of $\mathrm{COM}$ when $c\left(\mathrm{C}_{6} \mathrm{~S}\right) \leq 0.5 \mathrm{mg} / \mathrm{L}$, indicating that $\mathrm{C}_{6} \mathrm{~S}$ was easier to adsorb on the surface of COD crystallites. This result was contrary to that of micron-grade $\mathrm{COM}$ and COD crystals because the main crystal face (101) of the hexagonal micron COM was positively charged and very large, whereas the sites with high charge densities of the octahedral bipyramidal micron COD were only found at the apex of two vertexes of the crystal. Thus, the positive charges on micron COD were less than those on micron COM. However, when the size of COD decreased, the number of COD crystallites increased for the same mass of crystallites. The number of their pyramidal vertexes increased, so submicron COD had more charges than micron $\mathrm{COD}$, and its adsorption to $\mathrm{C}_{6} \mathrm{~S}$ was strengthened. By contrast, when the size of COM decreased, its main crystal face, the positively charged (101) face, became smaller. Therefore, the positive charges on the $\mathrm{COM}$ surface reduced, so the adsorption capability of submicron COM to $\mathrm{C}_{6} \mathrm{~S}$ decreased. As a result, the surface Zeta potential of submicron COD became more negative. The density of calcium ions on the COD surface was not significantly different from that of COM [29]. One calcium ion exists in about $0.305 \mathrm{~nm}^{2}$ to $0.459 \mathrm{~nm}^{2}$ of surface COD and about $0.383 \mathrm{~nm}^{2}$ to $0.455 \mathrm{~nm}^{2}$ of surface COM. A previous study [30] reported that negatively charged osteopontin is more strongly adsorbed on COD surface than on COM surface.

(4) Compared with $t=0 \mathrm{~h}$, the Zeta potential of COM and COD crystallites became slightly negative at $t=$ $48 \mathrm{~h}$ because the adsorbed $\mathrm{C}_{6} \mathrm{~S}$ on the crystallite surface became tighter and more orderly with the increase of acting time. Thus, the absorbed amount of $\mathrm{C}_{6} \mathrm{~S}$ molecules slightly increased.

3.4. $\mathrm{C}_{6}$ S Inhibits the Aggregation of COM and COD Crystallites. A nanoparticle size analyzer was used to study the effect of $\mathrm{C}_{6} \mathrm{~S}$ concentration on the mean diameters (Figure 6) and size distributions (Figure 7) of COM and COD particles. The results indicate the following.

(1) At $c\left(\mathrm{C}_{6} \mathrm{~S}\right)=0$, the crystallites were dispersed in pure water. The mean diameters of COM and COD were 1746 and $1668 \mathrm{~nm}$, respectively, which were much larger than the initial mean diameter of about $330 \mathrm{~nm}$ (Figure 1(b)). This result indicates that the 


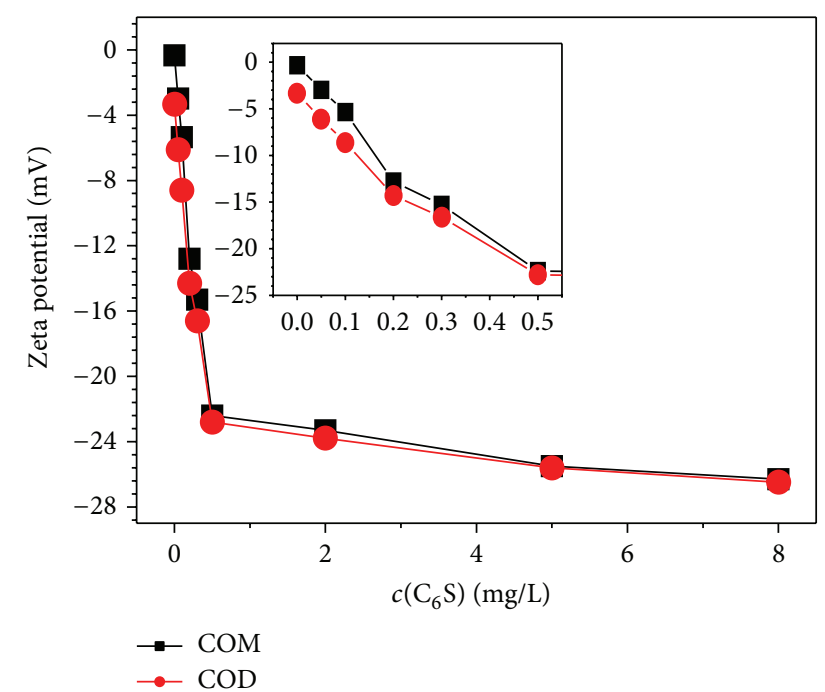

(a) $t=0 \mathrm{~h}$

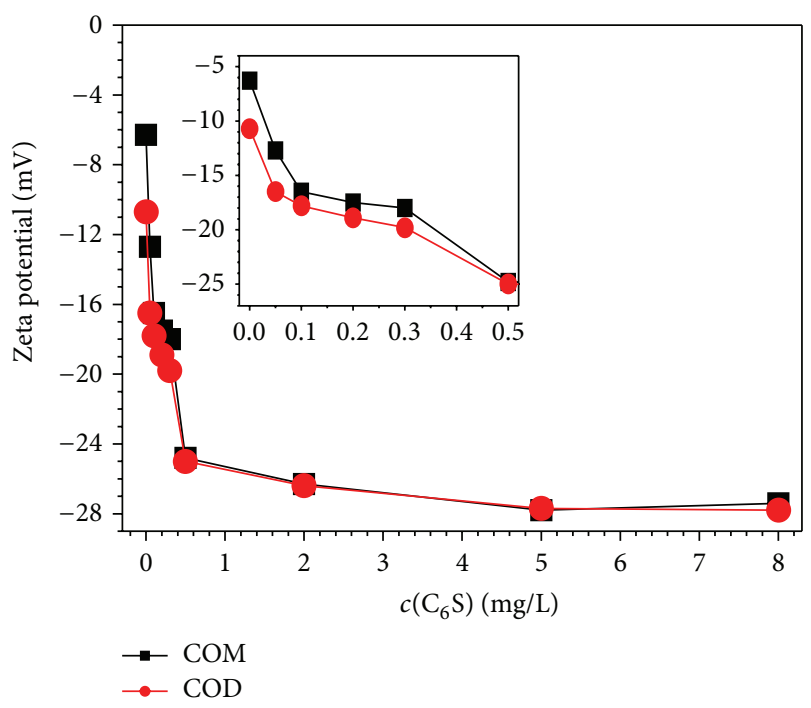

(b) $t=48 \mathrm{~h}$

Figure 5: Effect of $\mathrm{C}_{6} \mathrm{~S}$ concentration and acting time on Zeta potential of submicron COM and COD crystallites. (a) $t=0$; (b) $t=48 \mathrm{~h}$. The insets show the amplification figures when $c\left(\mathrm{C}_{6} \mathrm{~S}\right) \leq$ $0.5 \mathrm{mg} / \mathrm{L}$.

aggregation of both COM and COD crystallites in pure water was intensive.

(2) When $c\left(\mathrm{C}_{6} \mathrm{~S}\right)$ increased to $0.20 \mathrm{mg} / \mathrm{L}$, the mean diameters of COM (Figure 6(a)) and COD (Figure 6(b)) were close to their initial diameters, which indicated that this concentration of $\mathrm{C}_{6} \mathrm{~S}$ could entirely inhibit the aggregation of COM and COD in aqueous solution, inducing them to exist in a single crystal.

(3) When $c\left(\mathrm{C}_{6} \mathrm{~S}\right)$ increased from $0.5 \mathrm{mg} / \mathrm{L}$ to $2.0 \mathrm{mg} / \mathrm{L}$, the size changes in COM and COD crystallites were small, and both were close to the particle size of a single crystal. If submicron COM and COD crystallites are considered spheres, we could calculate that every 2.4 and $3.0 \mathrm{~nm}^{2}$ surface area of COM and COD, respectively, adsorbed one unit of $\mathrm{C}_{6} \mathrm{~S}$ molecule (one hexuronic acid and hexosamine unit, Figure 8) at $c\left(\mathrm{C}_{6} \mathrm{~S}\right)=0.5 \mathrm{mg} / \mathrm{L}$. Due to limited sites of calcium ions on the crystallite surface and the effect of steric hindrance of $\mathrm{C}_{6} \mathrm{~S}$, the adsorption of $\mathrm{C}_{6} \mathrm{~S}$ molecule on COM and COD crystallites was nearly saturated [31] at this point. The density of negative charges on the crystallite surface was the largest; that is, the Zeta potential on the crystallite surfaces became highly negative and the electrostatic repulsion between the crystallites was the strongest, so crystallite aggregation was inhibited [32].

When $c\left(\mathrm{C}_{6} \mathrm{~S}\right)>2.0 \mathrm{mg} / \mathrm{L}$ due to the excess adsorbed $\mathrm{C}_{6} \mathrm{~S}$ around the crystallite in the solution, the crystallite size slightly increased.

3.5. $C_{6}$ S Inhibits Deposition of COM and COD Crystallites. Model tests in vitro and animal experiments confirmed that the retention of urine crystallites in renal tubules is one of the important factors of stone formation [33-35]. After COM and COD crystallites were dispersed in aqueous solutions of $c\left(\mathrm{C}_{6} \mathrm{~S}\right)=0,0.1,0.5$, and $5 \mathrm{mg} / \mathrm{L}$, photos of these suspensions at different placement times were taken (Figure 9), and their sedimentation speeds were compared.

(1) At $t=0 \mathrm{~h}$, all the crystallites were dispersed, regardless if they were COM or COD and whether the concentration of $c\left(\mathrm{C}_{6} \mathrm{~S}\right)$ was 0 or $5.0 \mathrm{mg} / \mathrm{L}$.

(2) At $t=2 \mathrm{~h}$, the suspensions of COM and COD crystallites in the presence of $c\left(\mathrm{C}_{6} \mathrm{~S}\right)=0$ and $0.1 \mathrm{mg} / \mathrm{L}$ first sedimented and then their turbidities decreased. Submicron COM and COD had large specific surface areas and higher surface free energy, so they were easily aggregated and deposited in the aqueous solution when $\mathrm{C}_{6} \mathrm{~S}$ was absent or when $c\left(\mathrm{C}_{6} \mathrm{~S}\right)$ was very small.

(3) At $t=4 \mathrm{~h}$, the suspensions of crystallites in solutions of $c\left(\mathrm{C}_{6} \mathrm{~S}\right)=0$ and $0.1 \mathrm{mg} / \mathrm{L}$ almost completely deposited. However, the turbidity of the suspensions of $c\left(\mathrm{C}_{6} \mathrm{~S}\right)=0.5$ and $5.0 \mathrm{mg} / \mathrm{L}$ did not significantly decrease.

(4) At $t=24 \mathrm{~h}$, the turbidity of the suspensions of $c\left(\mathrm{C}_{6} \mathrm{~S}\right)$ $=0.50$ and $5.0 \mathrm{mg} / \mathrm{L}$ began to decline .

To quantify the sedimentation degree of COM and COD crystallites, a UV-vis spectrophotometer was used to measure the optical density of COM and COD suspensions after they were left to stand for $4 \mathrm{~h}\left(\mathrm{~A}_{t=4}\right)$ at a wavelength of $620 \mathrm{~nm}$ [24]. According to the calculation method of aggregation coefficient in the literature [36], the differences in the optical densities at $t=4 \mathrm{~h}\left(A_{t=4}\right)$ and $t=0 \mathrm{~h}\left(A_{t=0}\right)$ were defined as sedimentation coefficient (SC):

$$
\mathrm{SC}=\left(A_{t=0}-A_{t=4}\right) \times 1000,
$$

where the value 1000 was used to convert SC into an integer number from a decimal number. The larger the SC, the greater the deposition degree of crystallites in the suspension. The results are shown in Figure 10. 


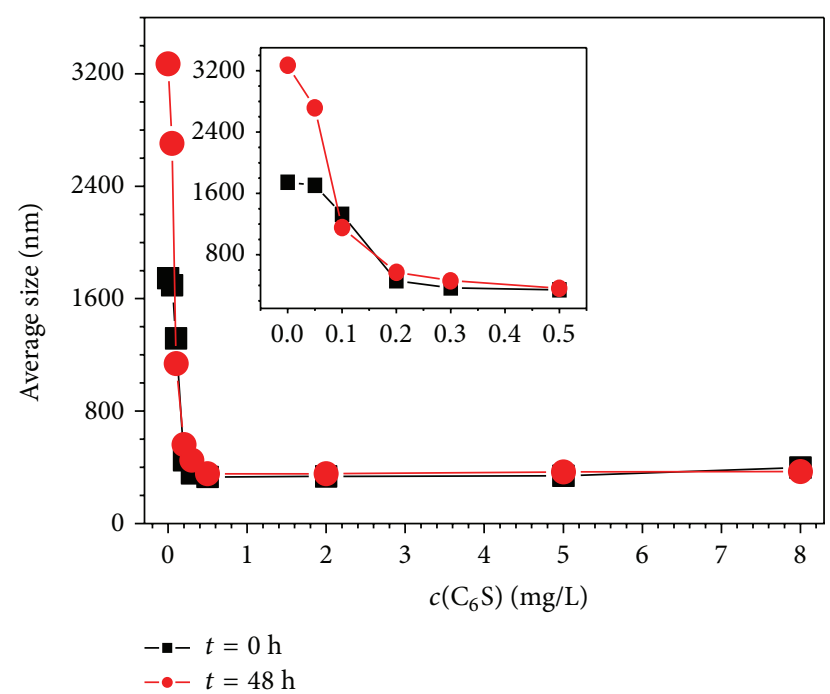

(a)

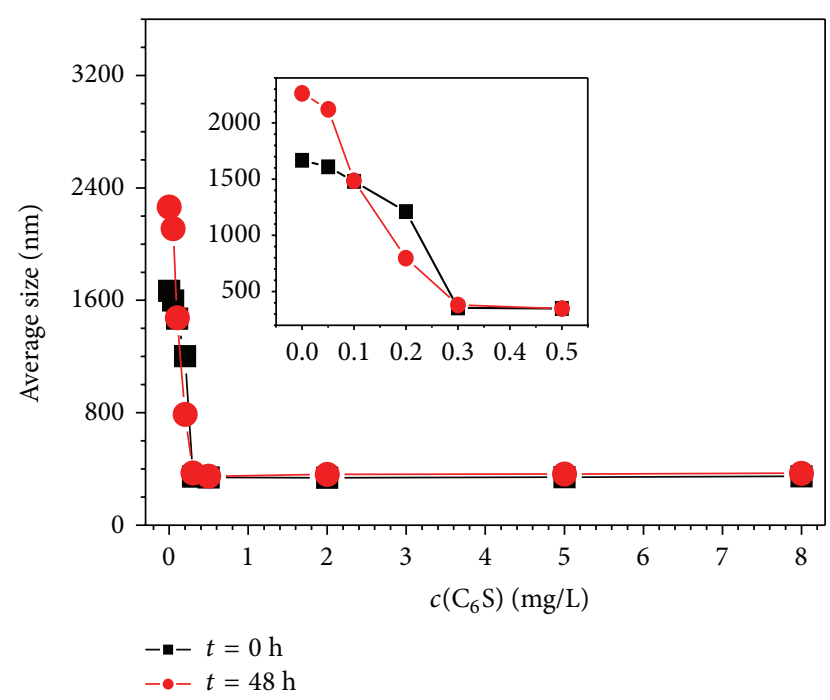

(b)

FIGURE 6: Effect of $\mathrm{C}_{6} \mathrm{~S}$ concentration on the average size of submicron COM and COD. (a) COM; (b) COD. Acting time: 0 and $48 \mathrm{~h}$.

(1) In the suspension $c\left(\mathrm{C}_{6} \mathrm{~S}\right) \leq 0.10 \mathrm{mg} / \mathrm{L}$, the SC values of both COM and COD were large, indicating that both COM and COD crystallites are easy to deposit in pure water or in diluted $\mathrm{C}_{6} \mathrm{~S}$ solution.

(2) At $c\left(\mathrm{C}_{6} \mathrm{~S}\right)=0.20 \mathrm{mg} / \mathrm{L}$, the $\mathrm{SC}$ values rapidly declined from 306 and 286 to 136, 110, respectively, for COM and COD crystallites.

(3) When $c\left(\mathrm{C}_{6} \mathrm{~S}\right) \geq 0.50 \mathrm{mg} / \mathrm{L}$, the SC values of COM and COD slightly changed, which was attributed to the adsorption of $\mathrm{C}_{6} \mathrm{~S}$ on the surface of COM and COD crystallites that reached saturation. Thus, the settlement of crystallites was effectively suppressed.

(4) At the same $c\left(\mathrm{C}_{6} \mathrm{~S}\right)$, the SC value of COD crystallites was slightly smaller than that of COM crystallites, indicating that the COD suspension was more

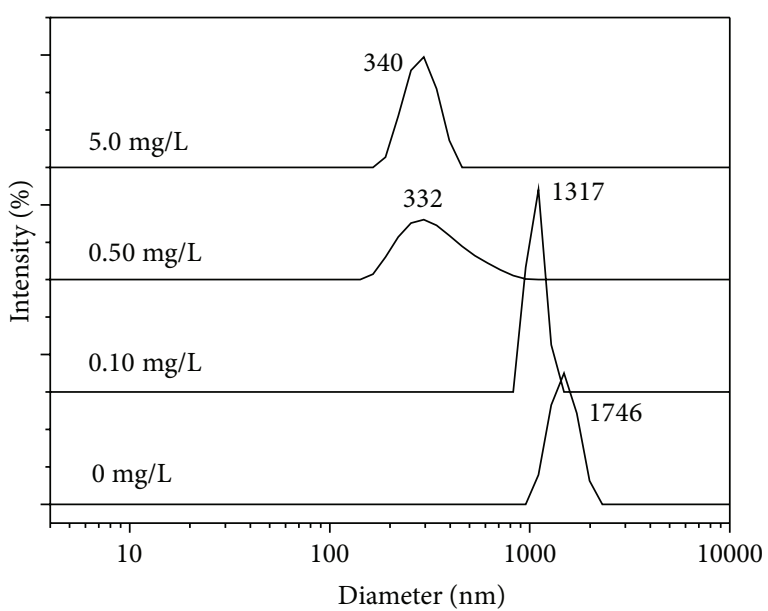

(a)

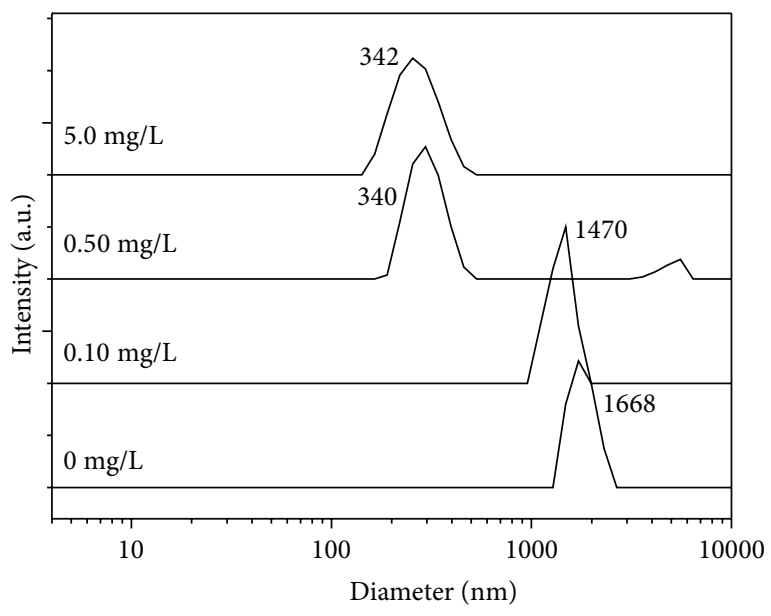

(b)

FIGURE 7: Effect of $\mathrm{C}_{6} \mathrm{~S}$ concentration on size distribution of submicron COM and COD crystallites. (a) COM; (b) COD. $t=0 \mathrm{~h}$.

stable than the COM suspension. This result was attributed to the following reasons. First, the mean particle diameter of COM and COD crystallites was nearly the same, but the density of COD crystallites $(2.02 \mathrm{~g} / \mathrm{mL})$ was smaller than that of COM crystallites $(2.20 \mathrm{~g} / \mathrm{mL})$. Moreover, the light COD crystallites were difficult to deposit. Second, one more crystal of water was present in the COD molecule than in the $\mathrm{COM}$ molecule, so the former more easily formed a hydrogen bond with the sulfate groups of $\mathrm{C}_{6} \mathrm{~S}$. Thus, the solubility of COD- $\mathrm{C}_{6} \mathrm{~S}$ complex was larger than that of COM- $\mathrm{C}_{6} \mathrm{~S}$ complex. Third, the Zeta potential of COD was slightly more negative than that of COM (Figure 5). Therefore, the electrostatic repulsion force between COD crystallites was slightly larger than that between COM crystallites. This finding can explain why stones did not easily form in the urine of healthy controls: the presence of more COD crystallites prevented their formation. By contrast, more COM crystallites were present in the urine of stone patients. 


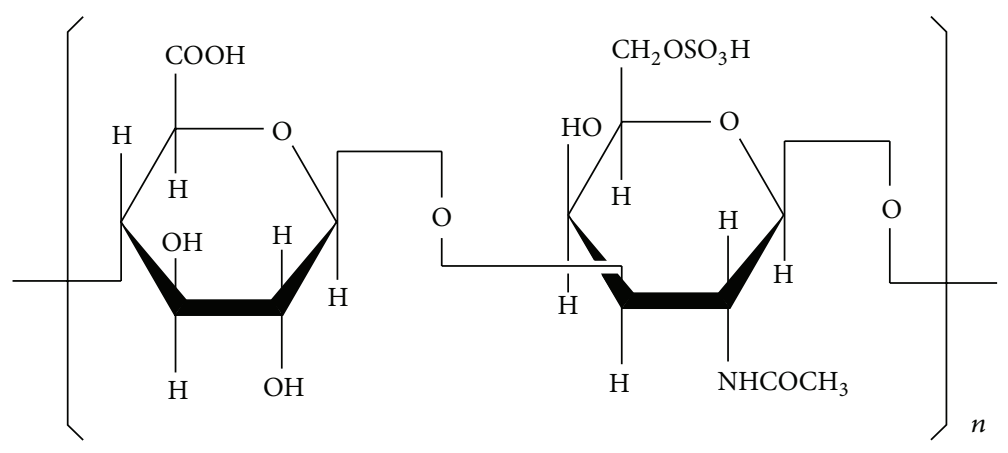

FIGURE 8: Chemical structure of chondroitin sulfate $\mathrm{C}\left(\mathrm{C}_{6} \mathrm{~S}\right)$.

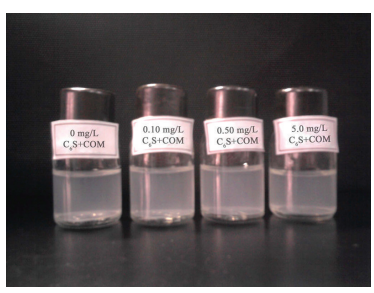

(a)

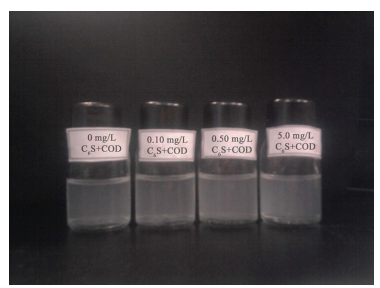

(e)

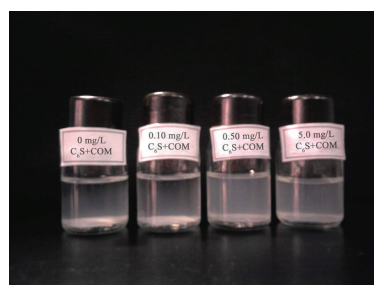

(b)

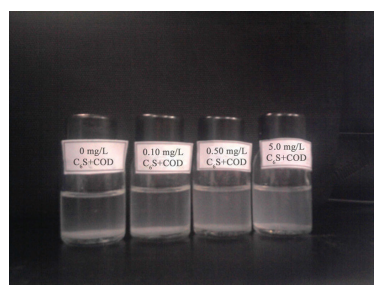

(f)

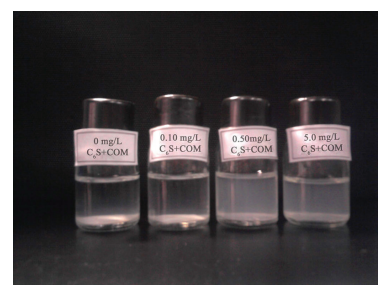

(c)

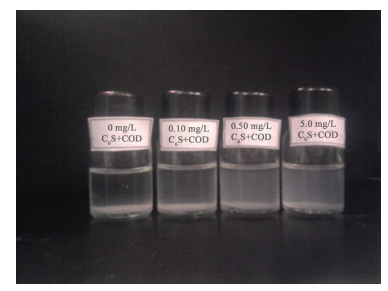

(g)

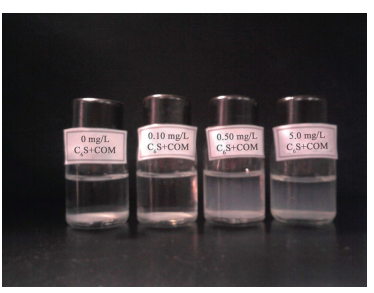

(d)

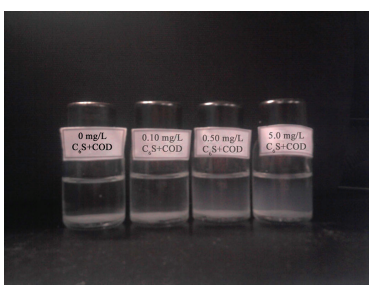

(h)

FIGURE 9: Photos showing sedimentation of the suspension of submicron COM and COD crystallites with placement time in presence of 0 , 0.1, 0.5, and $5 \mathrm{mg} / \mathrm{L}$ of $\mathrm{C}_{6} \mathrm{~S}$, respectively. (a)-(d) COM; (e)-(f) COD. (a) and (e) $0 \mathrm{~h}$; (b) and (f) $2 \mathrm{~h}$; (c) and (g) $4 \mathrm{~h}$; (d) and (h) $24 \mathrm{~h}$.

3.6. Inhibitory Mechanisms of $\mathrm{C}_{6} \mathrm{~S}$. GAGs are well-known macromolecular inhibitors found in urine and kidney stones [37]. $\mathrm{C}_{6} \mathrm{~S}$ is the major component of GAGs responsible for their inhibitory effect. The inhibitory mechanisms of $\mathrm{C}_{6} \mathrm{~S}$ include the following [38].

(1) $\mathrm{C}_{6} \mathrm{~S}$ is a linear polysaccharide polyanion. Each of its units has a negatively charged carboxylic group (uronic acid) and a negatively charged sulfate group [15]. These anions possess a strong capability to coordinate with $\mathrm{Ca}^{2+}$ ions. When $\mathrm{C}_{6} \mathrm{~S}$ binds with free $\mathrm{Ca}^{2+}, 1 \mu \mathrm{mol}$ chondroitin sulfate disaccharide unit binds with $0.757 \mu \mathrm{mol} \mathrm{Ca}^{2+}$, leading to increased concentration of soluble $\mathrm{Ca}^{2+}$ ions in urine, reduction in the saturation of $\mathrm{CaOxa}$ crystals, and inhibition of the nucleation and growth of $\mathrm{CaOxa}$ crystals [39].

(2) $\mathrm{C}_{6} \mathrm{~S}$ can increase the absolute value of the Zeta potential of $\mathrm{CaOxa}$ crystals by adsorbing on the surface crystals, resulting in the increase of electrostatic repulsion force between crystals and the inhibition of growth and aggregation of $\mathrm{CaOxa}$ crystals $[20,40]$.
(3) After their adsorption on the surface of CaOxa crystals, $\mathrm{C}_{6} \mathrm{~S}$ molecules with numerous negative charges close the sites for crystal growth and aggregation, leading to defects in crystal growth and prevention of the penetration of free crystal particles.

(4) $\mathrm{C}_{6} \mathrm{~S}$ can protect the mucosa of the urinary tract, thus preventing the adhesion of bacteria or other free particles on the surface of the urinary crystals.

The intake of drugs to prevent stone formation can increase urine GAG excretion, as manifested by the following examples. (1) The oral administration of pentosan polysulphate (SPP) can increase urinary GAG excretion; in fact, SPP is extensively used in the treatment of patients with renal calcium stone disease [41]. (2) After oral administration of Sterculia lychnophora Hance (a Chinese herb medicine), the urine GAG excretion in patients with renal calculi increased from $29.27 \pm 6.63 \mathrm{mg} / 24 \mathrm{~h}$ before drug intake to $35.94 \pm$ $7.29 \mathrm{mg} / 24 \mathrm{~h}(P<0.05)$ [42]. (3) The urine GAG excretion in patients with renal calculi increased from $31.2 \pm 6.5 \mathrm{mg} / 24 \mathrm{~h}$ before drug intake to $46.4 \pm 4.5 \mathrm{mg} / 24 \mathrm{~h}$ after the oral administration of WuIing Powder (a mixture of Chinese herb 


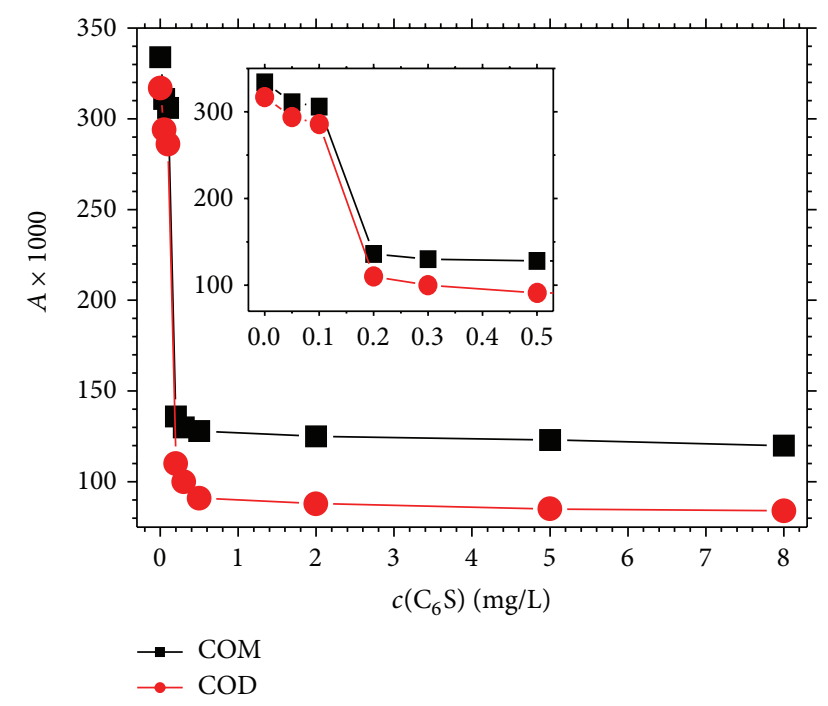

FIGURE 10: Sedimentation coefficient of suspensions of submicron $\mathrm{COM}$ and COD crystallites in the presence of different concentrations of $\mathrm{C}_{6} \mathrm{~S}$ after placement for $4 \mathrm{~h}$.

medicines) [43]. A significant difference was observed before and after the oral administration of WuIing Powder. (4) After $\mathrm{K}_{3}$ cit intake for 1 week, the GAG excretion from the urine of all 13 cases of $\mathrm{CaOxa}$ stone formers increased from $5.18 \pm$ $0.82 \mathrm{mg} / \mathrm{L}$ to $11.81 \pm 1.62 \mathrm{mg} / \mathrm{L}$ [33], whereas that of the control was $9.80 \pm 1.83 \mathrm{mg} / \mathrm{L}$. A significant difference was observed before and after $\mathrm{K}_{3}$ cit intake $(P<0.05)$.

Based on the discussion above, we can increase the excretion of chondroitin sulfate (i.e., GAGs) in urine through the intake of drugs to inhibit the formation of $\mathrm{CaOxa}$ calculi.

\section{Conclusions}

$\mathrm{C}_{6} \mathrm{~S}$ could increase the Zeta potential on the surface of submicron COM and COD crystallites with mean sizes of $330 \mathrm{~nm}$ as well as the electrostatic repulsion force between the crystallites. Thus, $\mathrm{C}_{6} \mathrm{~S}$ could inhibit aggregation and deposition of submicron COM and COD. $\mathrm{C}_{6} \mathrm{~S}$ could also inhibit the transformation of COD to COM. At the same $c\left(\mathrm{C}_{6} \mathrm{~S}\right)$ concentration, the Zeta potential of COD crystallites was more negative than that of COM, and the sedimentation coefficient of COD was smaller, so its suspension was more stable than that of submicron COM. These results indicated that $\mathrm{C}_{6} \mathrm{~S}$ could inhibit the formation of $\mathrm{CaOxa}$ stones. Therefore, we can increase the excretion of chondroitin sulfate in urine through the intake of drugs to inhibit the formation of CaOxa calculi.

\section{Conflict of Interests}

The authors declare that there is no conflict of interests regarding the publication of this paper.

\section{Acknowledgment}

This research work was supported by the Natural Science Foundation of China (81170649 and 21371077).

\section{References}

[1] C. Mechlin, C. Kalorin, J. Asplin, and M. White, "Splenda improves tolerance of oral potassium citrate supplementation for prevention of stone formation: results of a randomized doubleblind trial," Journal of Endourology, vol. 25, no. 9, pp. 1541-1545, 2011.

[2] J. P. Lulich, C. A. Osborne, M. Carvalho, and Y. Nakagawa, "Effects of a urolith prevention diet on urine compositions of glycosaminoglycans, Tamm-Horsfall glycoprotein, and nephrocalcin in cats with calcium oxalate urolithiasis," American Journal of Veterinary Research, vol. 73, no. 3, pp. 447-451, 2012.

[3] P. Viswanathan, J. D. Rimer, A. M. Kolbach, M. D. Ward, J. G. Kleinman, and J. A. Wesson, "Calcium oxalate monohydrate aggregation induced by aggregation of desialylated TammHorsfall protein," Urological Research, vol. 39, no. 4, pp. 269-282, 2011.

[4] W. Chiangjong and V. Thongboonkerd, "A novel assay to evaluate promoting effects of proteins on calcium oxalate crystal invasion through extracellular matrix based on plasminogen/plasmin activity," Talanta, vol. 101, pp. 240-245, 2012.

[5] D. Webber, A. L. Rodgers, and E. D. Sturrock, "Glycosylation of prothrombin fragment 1 governs calcium oxalate crystal nucleation and aggregation, but not crystal growth," Urological Research, vol. 35, no. 6, pp. 277-285, 2007.

[6] J.-Y. He, S.-P. Deng, and J.-M. Ouyang, "Morphology, particle size distribution, aggregation, and crystal phase of nanocrystallites in the urine of healthy persons and lithogenic patients," IEEE Transactions on Nanobioscience, vol. 9, no. 2, pp. 156-163, 2010.

[7] W. G. Robertson, "Kidney models of calcium oxalate stone formation," Nephron Physiology, vol. 98, no. 2, pp. p21-p30, 2004.

[8] J.-Y. He, J.-M. Ouyang, and R.-E. Yang, "Agglomeration of urinary nanocrystallites: key factor to formation of urinary stones," Materials Science and Engineering C, vol. 30, no. 6, pp. 878-885, 2010.

[9] N. K. Saw, P. N. Rao, and J. P. Kavanagh, "A nidus, crystalluria and aggregation: key ingredients for stone enlargement," Urological Research, vol. 36, no. 1, pp. 11-15, 2008.

[10] S. D. Roberts and M. I. Resnick, "Glycosaminoglycans content of stone matrix," Journal of Urology, vol. 135, no. 5, pp. 1078-1083, 1986.

[11] N. W. Poon and M. D. I. Gohel, "Urinary glycosaminoglycans and glycoproteins in a calcium oxalate crystallization system," Carbohydrate Research, vol. 347, no. 1, pp. 64-68, 2012.

[12] I. D. Thorne and M. I. Resnick, "A methodology for the characterization of urinary glycosaminoglycans," Journal of Urology, vol. 131, no. 5, pp. 995-999, 1984.

[13] W. Bodenstab, J. Kaufman, and C. L. Parsons, "Inactivation of antiadherence effect of bladder surface glycosaminoglycan by a complete urinary carcinogen (N-methyl-N-nitrosourea)," Journal of Urology, vol. 129, no. 1, pp. 200-201, 1983.

[14] T. Schwend, R. J. Deaton, Y. Zhang, B. Caterson, and G. W. Conrad, "Corneal sulfated glycosaminoglycans and their effects on trigeminal nerve growth cone behavior in vitro: roles for ECM in cornea innervation," Investigative Ophthalmology \& Visual Science, vol. 53, no. 13, pp. 8118-8137, 2012.

[15] N. Volpi, A. Mucci, and L. Schenetti, "Stability studies of chondroitin sulfate," Carbohydrate Research, vol. 315, no. 3-4, pp. 345-349, 1999.

[16] B. Erkurt, Y. Ilker, Y. Budak, B. Özveren, L. Türkeri, and A. Akdaş, "Effect of urinary stone disease and extracorporeal 
shockwave lithotripsy on excretion of glycosaminoglycans," Journal of Endourology, vol. 13, no. 8, pp. 553-557, 1999.

[17] Y. M. Michelacci, R. Q. Glashan, and N. Schor, "Urinary excretion of glycosaminoglycans in normal and stone forming subjects," Kidney International, vol. 36, no. 6, pp. 1022-1028, 1989.

[18] S. Srinivasan, P. Kalaiselvi, R. Sakthivel, V. Pragasam, V. Muthu, and P. Varalakshmi, "Uric acid: an abettor or protector in calcium oxalate urolithiasis? biochemical study in stone formers," Clinica Chimica Acta, vol. 353, no. 1-2, pp. 45-51, 2005.

[19] O. Miyake, K. Yoshimura, M. Tsujihata et al., "Possible causes for the low prevalence of pediatric urolithiasis," Urology, vol. 53, no. 6, pp. 1229-1234, 1999.

[20] S.-P. Deng and J.-M. Ouyang, "Effects of dipalmitoylphosphatidylcholine monolayers to the crystallization of calcium oxalate monohydrate from the solution containing chondroitin sulfate C," Colloids and Surfaces A, vol. 257-258, pp. 47-50, 2005.

[21] M. Masui, M. Suzuki, Y. Fujise, and N. Kanayama, "Calciuminduced changes in chondroitin sulfate chains of urinary trypsin inhibitor," Biochimica et Biophysica Acta, vol. 1546, no. 2, pp. 261-267, 2001.

[22] H. Peng, J.-M. Ouyang, X.-Q. Yao, and R.-E. Yang, "Interaction between sub-micron COD crystals and renal epithelial cells," International Journal of Nanomedicine, vol. 7, no. 8, pp. 47274737, 2012.

[23] J.-M. Ouyang, Z.-Y. Xia, G.-N. Zhang, and H.-Q. Chen, "Nanocrystallites in urine and their relationship with the formation of kidney stones," Reviews in Inorganic Chemistry, vol. 32, no. 2-4, pp. 101-110, 2012.

[24] S. Kulaksizoglu, M. Sofikerim, and C. Cevik, "Impact of various modifiers on calcium oxalate crystallization," International Journal of Urology, vol. 14, no. 3, pp. 214-218, 2007.

[25] M. Donnet, N. Jongen, J. Lemaitre, and P. Bowen, "New morphology of calcium oxalate trihydrate precipitated in a segmented flow tubular reactor," Journal of Materials Science Letters, vol. 19, no. 9, pp. 749-750, 2000.

[26] S. C. Lee, H. W. Choi, H. J. Lee et al., "In-situ synthesis of reactive hydroxyapatite nano-crystals for a novel approach of surface grafting polymerization," Journal of Materials Chemistry, vol. 17, no. 2, pp. 174-180, 2007.

[27] X.-J. Xu, Y.-M. Liu, H.-Y. Yu, and J.-M. Ouyang, “Thermodynamical transformation of calcium oxalate dihydrate and its stabilization by algal sulfated polysaccharide," Chinese Journal of Inorganic Chemistry, vol. 23, no. 4, pp. 640-644, 2007.

[28] M.-E. Laurence, P. Levillain, B. Lacour, and M. Daudon, "Advantage of zero-crossing-point first-derivative spectrophotometry for the quantification of calcium oxalate crystalline phases by infrared spectrophotometry," Clinica Chimica Acta, vol. 298, no. 1-2, pp. 1-11, 2000.

[29] A. Gul and P. Rez, "Models for protein binding to calcium oxalate surfaces," Urological Research, vol. 35, no. 2, pp. 63-71, 2007.

[30] R. L. Ryall, M. C. Chauvet, and P. K. Grover, "Intracrystalline proteins and urolithiasis: a comparison of the protein content and ultrastructure of urinary calcium oxalate monohydrate and dihydrate crystals," BJU International, vol. 96, no. 4, pp. 654663, 2005.

[31] M. Q. Ge and W. Y. Liang, "Adsorption of sodium dodecylbenzenesulfate (SDBS) on nanosized $\mathrm{CaCO}_{3}$ and dispersion of nanosized $\mathrm{CaCO}_{3}$ in water," Journal of Dispersion Science and Technology, vol. 31, no. 8, pp. 1157-1162, 2010.
[32] J. M. Baumann, B. Affolter, U. Caprez, C. Clivaz, Z. Gluck, and R. Weber, "Stabilization of calcium oxalate suspension by urinary macromolecules, probably an efficient protection from stone formation," Urologia Internationalis, vol. 79, no. 3, pp. 267-272, 2007.

[33] C.-Y. Duan, Z.-Y. Xia, G.-N. Zhang, B.-S. Gui, J.-F. Xue, and J.-M. Ouyang, "Changes in urinary nanocrystallites in calcium oxalate stone formers before and after potassium citrate intake," International Journal of Nanomedicine, vol. 8, no. 1, pp. 909-918, 2013.

[34] M. Tsujihata, C. Momohara, I. Yoshioka, A. Tsujimura, N. Nonomura, and A. Okuyama, "Atorvastatin inhibits renal crystal retention in a rat stone forming model," Journal of Urology, vol. 180, no. 5, pp. 2212-2217, 2008.

[35] K. Fong-Ngern, P. Peerapen, S. Sinchaikul, S.-T. Chen, and V. Thongboonkerd, "Large-scale identification of calcium oxalate monohydrate crystal-binding proteins on apical membrane of distal renal tubular epithelial cells," Journal of Proteome Research, vol. 10, no. 10, pp. 4463-4477, 2011.

[36] K. G. Christmas, L. B. Gower, S. R. Khan, and H. El-Shall, "Aggregation and dispersion characteristics of calcium oxalate monohydrate: effect of urinary species," Journal of Colloid and Interface Science, vol. 256, no. 1, pp. 168-174, 2002.

[37] J.-M. Ouyang, S.-P. Deng, J.-P. Zhong, B. Tieke, and S.-H. $\mathrm{Yu}$, "Crystallization of calcium oxalate monohydrate at dipalmitoylphosphatidylcholine monolayers in the presence of chondroitin sulfate A," Journal of Crystal Growth, vol. 270, no. 3-4, pp. 646-654, 2004.

[38] J.-M. Ouyang, M. Wang, P. Lu, and J. Tan, "Degradation of sulfated polysaccharide extracted from algal Laminaria japonica and its modulation on calcium oxalate crystallization," Materials Science and Engineering C, vol. 30, no. 7, pp. 1022-1029, 2010.

[39] A. Hesse, H. Wuzel, and W. Vahlensieck, "Significance of glycosaminoglycans for the formation of calcium oxalate stones," American Journal of Kidney Diseases, vol. 17, no. 4, pp. 414-419, 1991.

[40] J.-M. Ouyang, "Chemical basis in the investigation of calcium oxalate stones," Chemistry, vol. 65, no. 5, pp. 326-332, 2002.

[41] B. Fellstom, U. Backman, B. Danielson, and B. Wikström, “Treatment of renal calcium stone disease with the synthetic glycosaminoglycan pentosan polysulphate," World Journal of Urology, vol. 12, no. 1, pp. 52-54, 1994.

[42] S.-S. Zhang, G.-D. Liu, and J.-Y. He, "The experimental result and clinical observation of Sterculia lychnophora Hance inhibiting the formation of calcium oxalate crystals," Chinese Journal of Urology, vol. 17, pp. 51-53, 1996.

[43] X.-L. Kang, J.-Y. He, Y.-R. Chen, and G.-D. Liu, "The effect of wuling powder on inhibition of calcium oxalate crystallization and urinary GAGs excretion," Chinese Journal of Urology, vol. 12, no. 3, pp. 227-230, 1991. 

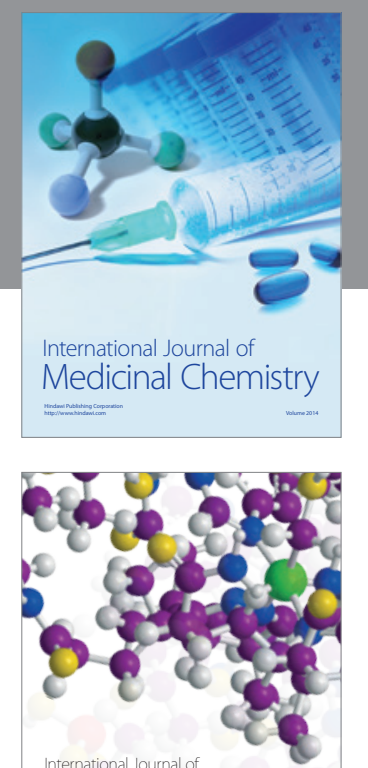

\section{Carbohydrate} Chemistry

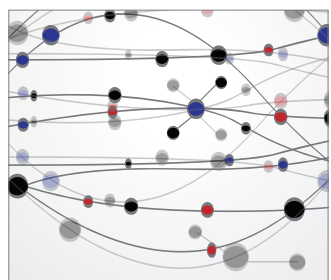

The Scientific World Journal
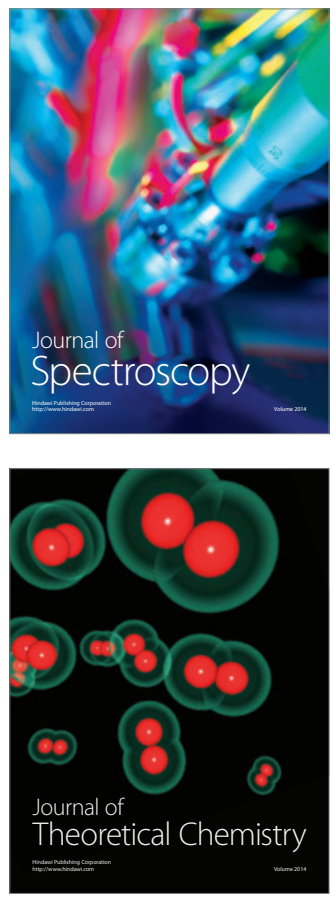
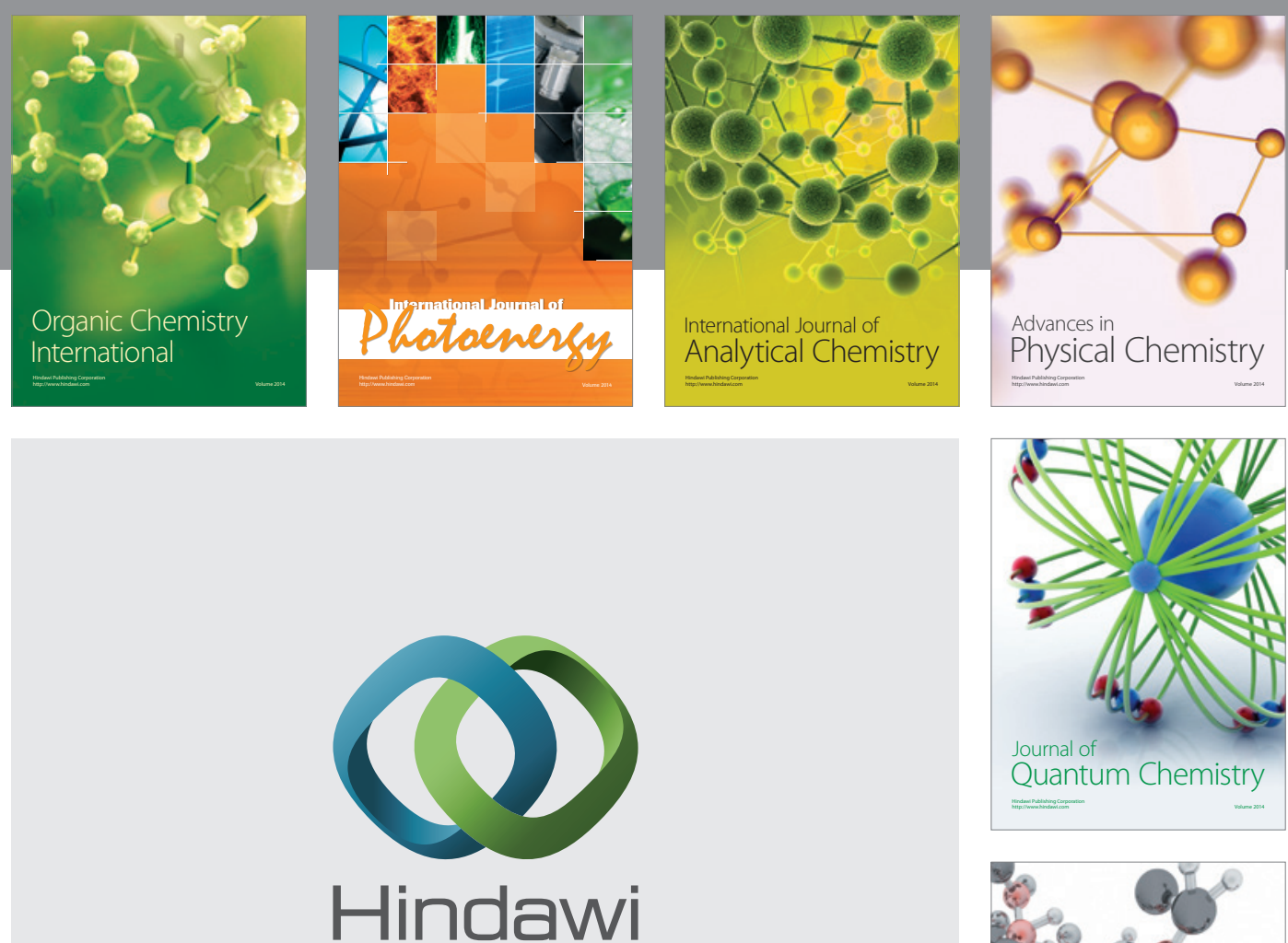

Submit your manuscripts at

http://www.hindawi.com

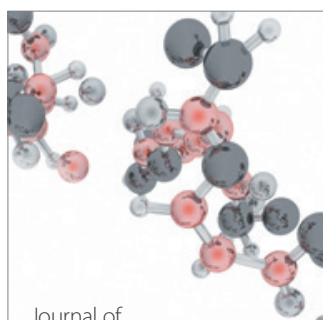

Analytical Methods

in Chemistry

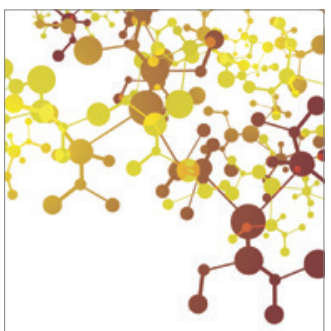

Journal of

Applied Chemistry

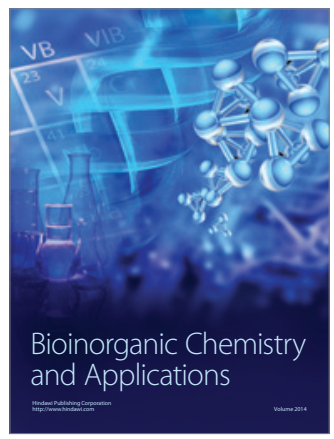

Inorganic Chemistry
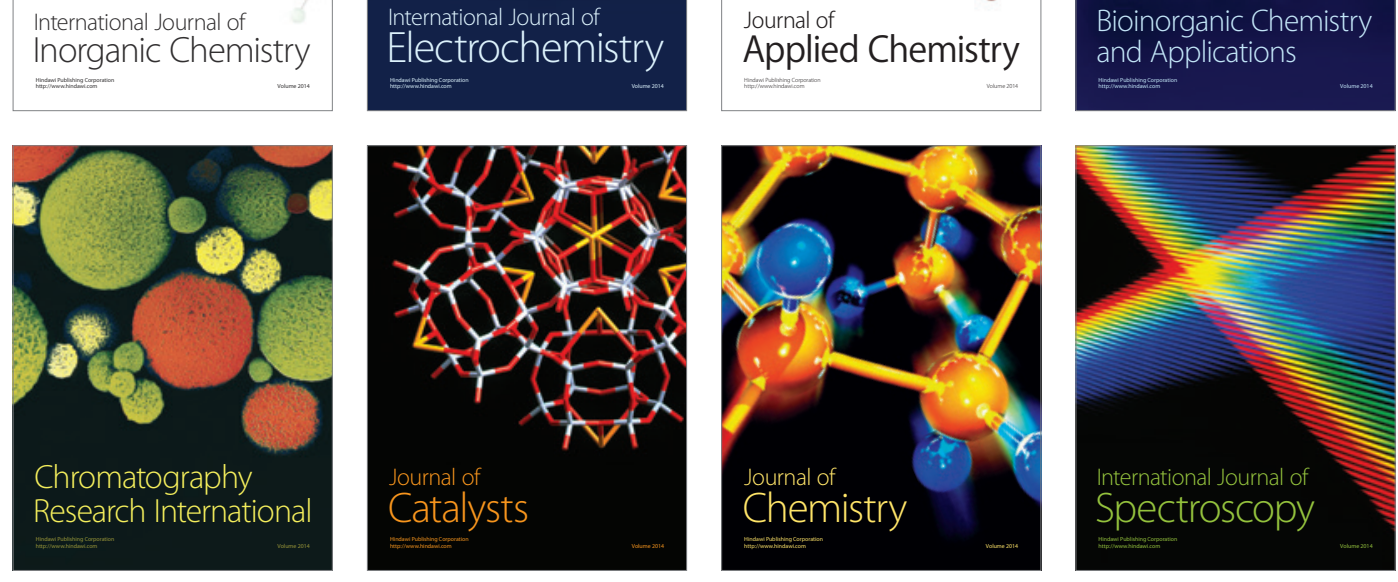